\title{
THE NEIGHBORHOOD OF FLORENTIN: A WINDOW TO THE GLOBALIZATION OF TEL AVIV
}

\author{
Caroline ROZENHOLC \\ University of Poitiers - MIGRINTER, University of Clermont-Ferrand, France
}

\begin{abstract}
Aside from open conflicts within Israel-Palestine, the neighborhood of Florentin is a key-space where to observe and decipher how globalization impacts on the daily-life scale and banal forms of identification and territorial appropriation. Situated south of the Tel Aviv Jaffa agglomeration, and standing in between the two historical entities, the neighborhood of Florentin also offers a fertile analytic ground for a better understanding and different narrative of Tel Aviv itself as well as the contemporary Israeli society in some of its complexity and diversity. Here, graffiti and other traces left in the streets and on the walls of Florentin by successive waves of population constitute the thread to follow for deep-reading the place.
\end{abstract}

Key Words: globalization, diversity, sense of place, identification, territorial appropriation, Tel Aviv-Jaffa, Florentin neighborhood, graffiti

\section{Introduction: Israel, Tel Aviv, the neighborhood of Florentin and globalization}

Thinking about diversity and globalization, Israel-Palestine does not often come to mind first. Neither does the "singularity" of Israel ease the generalization from case studies conducted in the region on global-local topics. On the contrary, working in Israel, the social scientist's attention is most likely to be attracted by the geopolitical intensity of ongoing conflicts and dramatic events. The new forms of territorial appropriations and identity claims are thus rarely seek in the banal ${ }^{1)}$ aspects of globalization and more, the societal evolutions of Israel are seldom investigated through the triviality of daily-urban-life. Thus, wishing to contribute to the debates on globalization and diversity from Israel and as an attempt to shift forward the practice of social sciences in and on Israel, this article will present a reflection on the city of Tel Aviv from a geographical point of view. But if Tel Aviv is more and more publicized as the coalescence of an open-to-world and tolerant Israel - the total "flipside of Jerusalem"2) - the attempt of this article is to go in the depth of the city and to see what is underneath the festive and postmodern reputation of Tel Aviv.

Therefore, the focus is not on the prosperous Tel Aviv - neither on the business quarters nor on the Bauhaus Unesco Worldwide Heritage site - but on one of Tel Aviv historical southern neighborhoods: the neighborhood of Florentin. Florentin emerged only recently from marginality to be "put back" on the map of Tel Aviv and yet, with about 6000 inhabitants and after decades of decay, this small neighborhood is today strongly identified with the cosmopolitan youth and

1) This is specifically true for non-Israeli social scientists working on Israel-Palestine but it can also be traced within the Israeli academia. Of course, there are major exceptions to that general trend (see bibliography).

2) According to a recent article published online in the Israeli Haaretz newspaper ( $1^{\text {st }}$ of November 2010), "Lonely Planet this week named Tel Aviv third in a list of the world's best cities, praising the coastal metropolis for its art and music scenes and relaxed, liberal culture", http://www.haaretz.com/news/national/ tel-aviv-is-in-top-three-cities-in-the-world-says-lonely-planet-1.322274. 
global atmosphere of Tel Aviv. Its "dark" reputation accumulated through years of poverty and lack of municipal concern is nowadays dissolving into a sense of "authenticity". Interestingly, in the last years, for people settling in Florentin, this sense of "authenticity" mixes with a desire for "exoticism" sustained as much by the presence of Asian and African migrant workers, Palestinian and working class families as by a whole range of small bakeries, groceries and spices boutiques, smiths and tapestries workshops, and restaurants serving from "homecooking" to Indian talhis and Japanese sushi.

\section{Looking at the global through the local}

The streets of Florentin thus offer a unique and particularly rich accumulation of layers of activities and presences. By this accumulation itself, and through the complexity it produces, the streets present to the patient observer (as well as the punctual visitors) some elements testifying of the new "arrangements" of the contemporary Israeli society regarding identity, identification and territorial urban appropriation. In addition, a detailed reading of the neighborhood of Florentin - through in-depth interviews on the "life in the neighborhood" and archive work in the Municipality of Tel Aviv Jaffa crossed with street observation and photography - also reveals a different narrative of Tel Aviv than the one largely admitted of an apolitical and somehow de-territorialized city. Looking at Tel Aviv through the history of Florentin and the southern neighborhoods indeed helps rooting, surprisingly, a city often labeled as "the Bubble" in its geopolitical surroundings and settings. It shows a whole range of different faces and a larger panel of intermediate colors between the Black and the White cities. The neighborhood of Florentin thus functions theoretically both as a prismatic window through which to observe the globalization of the city and as a microcosm from where to analyze the ongoing social evolutions of the country. Therefore, by diving in this pulsating economical and cultural core of Israel, we want to show how and why one of its rather marginal neighborhoods emerged recently as a centrality from where to decipher what is, on the one hand, the "place" and sense of place today and, on the other hand, to understand how territorial identification works in Israel today.

By doing so, the challenge of looking at the global through place-based research, leads to knit a whole web of local and global scales and to reposition the local in its frame, being it the city, the country or the region. Trying to understand the specificities of the very place of Florentin and then generalizing from this case-study in Israel, I suggest that from a methodological point of view and as much as for the practice of Geography, this research on the neighborhood of Florentin can serve as a paradigmatic example to understand place-making in other contexts. Indeed, if we stick with the basic geographical preoccupation of how space and society intertwine, I argue that the effort of navigating among scales (of time and space) and strata of meanings has become, like it is for understanding the place of Florentin in Tel Aviv along the history of city, a methodological necessity. It helps clearing up the "place" a place bears in the

3) These reasoning process and methodological choice are detailed in the $\mathrm{PhD}$ thesis in Geography on which this article is based: "Florentin (2005-2009): a neighborhood of Tel Aviv in the globalization or how to read a place to tell about the city". The original title is in French: "Lire le lieu pour dire la ville. Florentin: une mise en perspective de Tel Aviv dans la mondialisation (2005-2009). It is based on a four years fieldwork conducted between 2005 and 2008. The PhD itself was concluded and defended in May 2010.

4) Since the 1920s, Tel Aviv has been nicknamed the bubble (Shavit 2004). More recently, this nickname has become very popular through Eytan Fox's movie "The Bubble", "Ha'bouah" (2007) in Hebrew.

5) The themes of the Black and the White cities are largely developed by the Israeli architect Sharon Rotbard, especially in his book (2005) Ir levana, ir shrora, Tel Aviv, Babel (in Hebrew). 
complex ensembles cities constitute today and it is a key to understand the constitution of the urban and social fabrics; how it is created and sometimes unraveled.

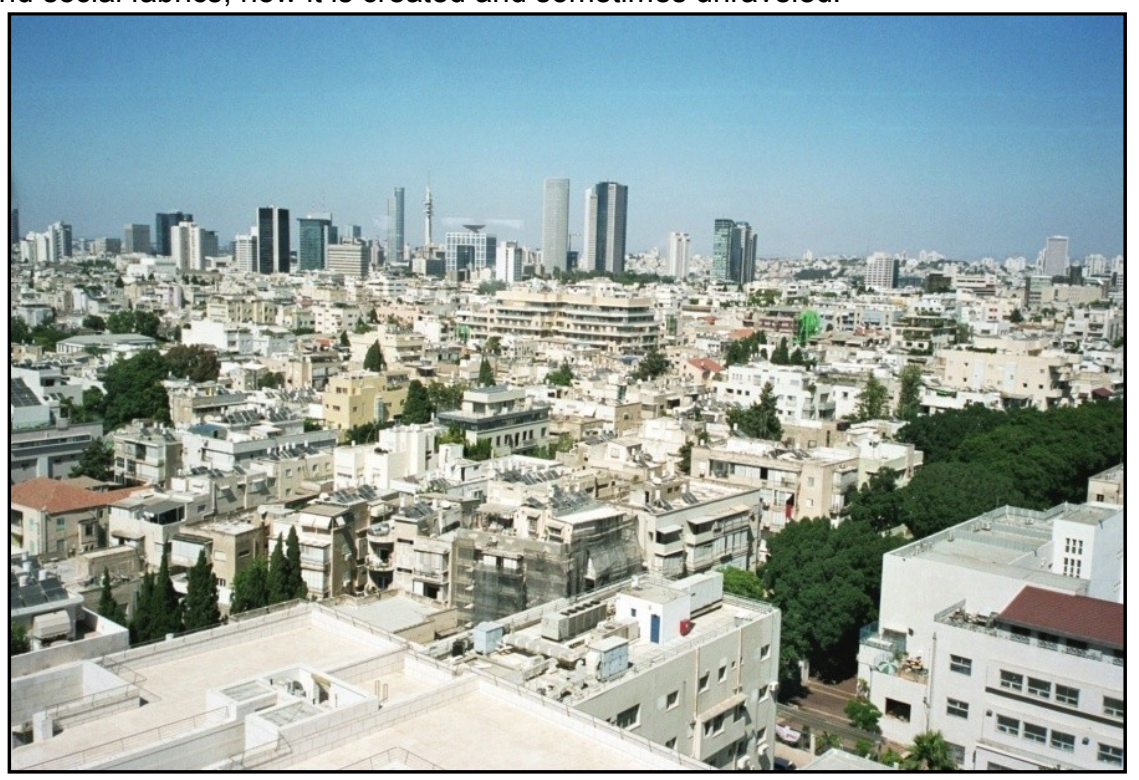

Fig. 1- Tel Aviv in 2008 with the business quarter and its high-rises in the background and the trees of Rotschild Boulevard on the right side of the picture

\section{Tel Aviv: a restless urban landscape ${ }^{6)}$}

The tensions in the Middle East are so prevalent and the categories of the conflict in IsraelPalestine so dominant that they concentrate a lot of the social research. Observers reflecting on Israel have indeed embodied the habit of addressing topics and places through the most dramatic situations, leaving aside the mundane, yet crucial, urban settings and their ongoing transformations. As put by Saskia Sassen (2005) in her reflection on globalization, the master categories of State and conflict have a "blinding power" of explanation ${ }^{7}$. They thus leave in the penumbra a very active part of the social reality. And this is why, precisely, digging in Tel Aviv, and in its less known aspects, might be efficient and informative.

Tel Aviv metropolitan area is about 3 millions of inhabitants and, as such, it is the biggest metropolis in Israel. Its inner ring composed of the agglomeration of Tel Aviv Jaffa (as illustrated on figure 2) represents about one tenth of the metropolis population (390 000 inhabitants according to the municipal statistics of 2009 - Statistical Yearbook 2009) and it concentrates most of the cultural and economical activity of the region. It surely is today, and

6) Lin and Wei (2002) quoted by Bonard and Felli (2008) use this expression of "restless urban landscape" to qualify the evolutions of the Chinese urban landscape.

7) Saskia Sassen's argument (2005: 402) about master categories and their explanatory power is very efficient in the attempt of breaking through the methodological nationalism prevalent in researches on Israel-Palestine: "From where I (Sassen 2006) look at it all, master categories have the power to illuminate, but theirs is blinding power thereby also keeping us from seeing other presences in the landscape. They produce, then, a vast penumbra around that centre of light. It is in that penumbra that we need to go digging". 


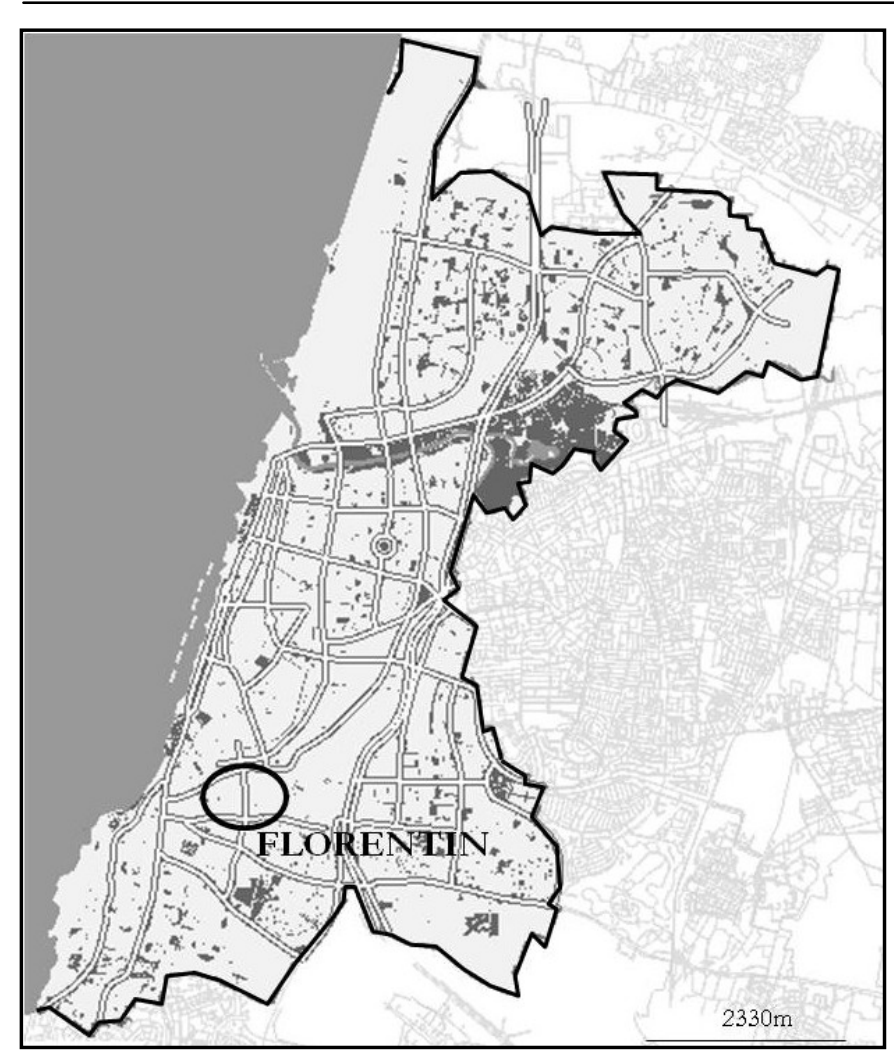

Fig. 2 - The neighborhood of Florentin, South of the Tel

Aviv - Jaffa agglomeration (source: Municipality of Tel Aviv Jaffa, http://gis.tel-aviv.gov.il/iview/).

happened to be within only 100 years ${ }^{8)}$, the cosmopolitan and high-tech hub of the country. About Tel Aviv we need to point out how peculiar in the Israeli landscape the city is and how different from the rest of the country the city feels. In this sense, the nickname the city bears - not many cities have nicknames! - echoes the distance Tel Aviv seems to retain from its troubled context. Tel Aviv is often perceived, both in and outside the country, as a place of leisure and quality of life. A-political and somehow unquestioned, the global Tel Aviv stands, for example, and apparently more than ever as the complete opposite of Jerusalem (Alfasi and Fenster, 2005; Ram, 2008). The city almost seems disconnected from its geography and the myth of Tel Aviv rising from bared dunes is still strong ${ }^{9}$. To complete the picture of what is Tel Aviv today, we have to mention that the UNESCO nominated the city in 2003 as a site of the World Wide Heritage. And this nomination surely added to the aura and prestige of the city, with a new emphasis on the city Bauhaus architecture and European urban planning. This nomination also showed a rather new patrimonial awareness for Tel Aviv. From 2003, many investments were brought to the center of the city but most of them didn't really pass the border between the center and the south of the city. As such, this development contributed to reinforce existing borders and discrepancies among the city.

The city itself is divided today in three statistical areas, from North to South. The neighborhood of Florentin is situated on the southern part of the city, just across the administrative boundary between the center and the southern areas. Until 1948 this administrative border between neighborhoods was the historical border between Tel Aviv and Jaffa. This single fact of having a border in the city is, and has been, of great importance for the functioning of Jaffa and Tel Aviv. This is especially true for neighborhoods like Florentin that stand in between two different,

8) Usually, the creation of Tel Aviv is dated from the creation, in 1909, of the Jewish neighborhood Ahuzat Bait in the Municipality of Jaffa which changed its name to Tel Aviv in 1910.

9) In her article "Narrative-Myth and Urban Design", the geographer Iris Aravot (1995: 82) writes that "Tel Aviv was a very unusual phenomenon. Its growth from Ahuzat Bayit, the European neighborhood of Jaffa, to the largest city in Israel arose from sheer necessity rather than from ideological preferences. Thus Tel Aviv originally had no relation to a recommended model or to a general urban myth". 
and to some extent opposed, entities. If the political significance and social impact of this limit have been "forgotten" along the years, it never fully dissolved. Today it is what explains how the city articulates (or disarticulates) Jaffa and Tel Aviv and the development of Tel Aviv and "opposition" of Southern and Northern Tel Aviv. In the neighborhood of Florentin which interest us here, this partition is still literally marked on the ground as Florentin is still governed by two master plans, respectively the Yaffo B plan for Jaffa in its southern part and the Taba 48 for Tel Aviv in its northern part.

Being partly built under the jurisdiction of Jaffa and partly under the jurisdiction of the, at the time, new Tel Aviv, the neighborhood is literally situated in the frontier space between Tel Aviv and Jaffa. To some extent, and until today, it stands between what still represents modernity and tradition, between the "white" city of Ashkenazi middle class and the "black" South where the Sephardic working class and Palestinian families live. But to understand why Florentin, despite of being one of Tel Aviv historical neighborhoods, remained "out of the map" and distant from the White and prosperous city for many years, we need to follow the traces and signs the streets unveil and get to the history of the place. To understand why it was left aside from the narrative of the Bauhaus and patrimony Tel Aviv until now we need to go back to the beginning of the $20^{\text {th }}$ century and to remember that Tel Aviv was at that time a political center and its development: a national issue. And simply by placing those elements, we start to understand Florentin as the junction where Jaffa and Tel Aviv meet but also as a place of rupture within the metropolis between the old city of Jaffa and the White central city area of the Bauhaus Tel Aviv ${ }^{10)}$. This is what makes it so interesting, and this is where reside the challenge of researching in places of interstices, as we need to circulate among geographical scales and time to understand this very place and its changing meanings.

The choice of Florentin for studying globalization and diversity gets confirmed when we understand that among between 5000 to 7000 inhabitants $^{11)}$ can be find the widest panel of the Israeli population, from citizens to foreigners and all the people who stand in-between those two categories. The Municipality itself participates to this reading of Florentin as it proposes tourist tours of the neighborhood where to get some taste of the authenticity of the city and of the melting-pot of the Israeli society ${ }^{12}$. Truth is that Florentin is now changing, and both the population figures and the place itself show how much the neighborhood is reinvested today with constructions and renovations. More people come to live in Florentin, younger ones, and by doing so they too add new layers of meaning to this place. The interest of Florentin is that because it stands on the other side of the border it has preserved a certain rhythm and all strata of successive migration waves and presences in the neighborhood. Therefore, Florentin became kind of " exotic " and " authentic " in the globalized and fast changing Tel Aviv and Israeli society as it lives reachable elements that have disappeared elsewhere.

10) In 2003, Tel Aviv has been nominated as a worldwide heritage site by the UNESCO. This nomination concerns what is now commonly called the White city and roughly designates the Bauhaus and International Style building constructed in the limits of the Geddes plan of 1925.

11) The Municipality tends to estimate the population to 5000 inhabitants while local organization present much higher figures. The discrepancy lies in what the borders and the density are considered to be.

12) The Municipality proposes two tours of Florentin and its surroundings and the following quotes are withdrawn from the city hall website: "Taste and Color in South Tel Aviv : A tasting tour passing through the streets of South Tel Aviv, through the lanes and food stands of the Lewinsky Market. A tour between the sacks of fragant spices, a marzipan factory, soda kiosk, a little Turkish borecas store and more. The tour includes many opportunities for tasting" and "The Awakening of Florentin : A tour of one of Tel Aviv old neighborhoods, which had been undergoing a revival in the last few years, where new immigrants live next to veterans, students and artists, religious and secular. A genuine melting pot of Israeli society. The tour includes a visit to the LEHI". 


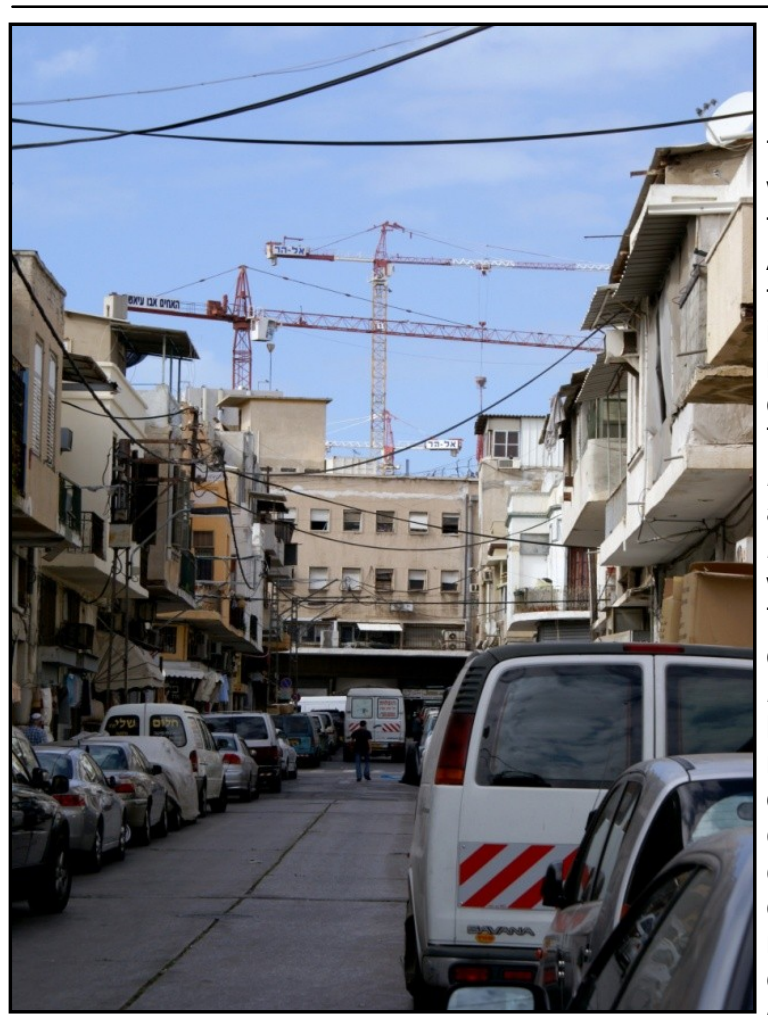

Fig. 3 - The neighborhood of Florentin has a unique architecture among Tel Aviv with buildings on the street, shops on the ground floors and dwellings on the second and third floors.

the creation of the neighborhood of Florentin ${ }^{15)}$. For the Israeli historian Tom Segev (2001, 183), the autonomy of Tel Aviv in 1921 is the most important Zionist achievment since "since Britain was given the Mandate. It was a cornerstone of Jewish autonomy in Palestine".

Nevertheless, after the creation of the State of Israel and the conquest of Jaffa in 1948, the neighborhood was "withdrawn" from the city map. From the 1950s it started half a century of deprivation regarding municipal investments and social infrastructures. Florentin area was even set for evacuation in 1954 by one of the city planners ${ }^{16)}$. By then, the neighborhood is supposed to be strictly dedicated to an industrial activity and starts by then to be officially perceived as inappropriate for living. This plan was never put in action, neither were

13) I borrow this idea of a fertile ground of research from Anne Raulin (2008: 67). by side.

14) Until 1950 and the dissolution of the Municipality of Jaffa, both municipalities will function side

15) Today, the ancient city of Jaffa is included in the Municipality of Tel Aviv Jaffa and constitutes one of its quarters. pp. I-IV.

16) A. B. Horwitz, "Master Plan for Tel Aviv-Yafo", TAMA, Yediot Tel Aviv - Yafo, 22 (8-9), 1954, 
renovations to compensate the degradation of the area. Still, it is important to note that this plan and perspective echoes the terms used by the British Authorities at the end of the 1940s to qualify the neighborhoods in between Tel Aviv and Jaffa ${ }^{17}$.

The combination of such factors and the gloomy reputation the neighborhood acquired over the years quickly turned Florentin into a place where you wouldn't want to live. Much of its population had left by the mid-1990s. But, nonetheless, and after years of decay, a local mobilization emerged and attracted the municipals attention to the poor situation of the neighborhood and the urgent need for changes. Combined with the municipal understanding of the potential of the neighborhood and its unique architecture - Florentin is the only place in Tel Aviv to be planned with low buildings straight on the street and to combine commercial, industrial, leisure and residential activities ${ }^{18)}$ - it initiated a reverse movement. Money was injected to publicize the place and to incite people to come back to the neighborhood. Between 1992 and 1995, more than four millions of dollars are spent in a communication and revitalization campaign: publicity and rent subsidies, kindergarten renovation, street pavement and street transformation for pedestrians, creation of a community centre (Bigger and Shavit, $2001)^{19)}$. Those public investments both then initiated and carried on spontaneous (private) transformations of businesses and dwellings. Between 1990 and 1995, six hundreds of apartments previously used as stock space or businesses are turned back by their owners to their residential use (Carmon, 1999). Sur la même période, les loyers et le prix d'achat des appartements doublent (Erez, 1996). From 2410 inhabitants in 1990, the population of Florentin rose to 3641 in 2000 and to 5197 inhabitants in 2009 20 ).

This movement initiated a general - although at first very much localized around Florentin Street - revitalization of the neighborhood, upped by the recognition of its unique atmosphere of cultural vitality and mixed population, being Israeli nationals from different backgrounds or migrant workers. Both in terms of activities and population, Florentin is, at the time and until today, a mixed neighborhood for dwellings and businesses, with shops and workshops on ground floors and dwellings in the upper ones. You find there carpentries and smiths and the noise of sewing and stapling machines is a full feature of the sound-scape of Florentin. The neighborhood of Florentin is the only place for such production in the city. All contributed from the 1990s to redefine the position and the image of Florentin among Tel Aviv metropolis. Pop songs from well-known artists such Ehud Banaï (with his song Florentin 1992) and Eytan Fox's "Florentin" TV series participated to a large extant to establish and diffuse on a national scale the idea of this neighborhood as an alternative place for living, self-definitions and identity construction a part of the Israeli youth. Florentin then started to appear as a bohemian, generous, tolerant and tough neighborhood. Today's real estate fever only confirms what can be formulated today as a quest of exoticism, at home, within even the limits one of Israel big city. The neighborhood thus slowly but surely transforms from a remote space within the city -

17) « I also wish to draw your attention to the deplorable fact of the growing number of slums in these quarters when all efforts in England and elsewhere are directed towards the abolition of slums and the introduction of modern systems of building which would reduce poverty in residential quarters » Notes to the District Commissioner Mr. Fuller, $21^{\text {tt }}$ of July 1947, Tel Aviv Municipal Archives, shhunot klali dossier n04-2209 B - 01-1944 - 03.1949.

18) Florentin was not planned according the Geddes plan and it was not either planned according Tel Aviv policy which recommend to have

19) About 12 millions and a half of New Isreaeli shekels (12 571 700) are spent in five years. About half of it is spent in the only year 1992 (6 043900 NIS) (Erez 1996).

20) The total population of the city of Tel Aviv rose from 339354 in 1990 to 354428 in 2000. It is now estimated to be about 392500 (Municipality of Tel Aviv Jaffa Statistical Yearbooks). In the same time period, the population of Florentin was multiplied by 2.15 (the population of Tel Aviv by 1.15). 
the "margin" within - into an "authentic" place in the constantly and fast changing "Bubble" Tel Aviv.

\section{Untangling geographical theory and sense of place through observation}

If we now zoom out the field, I can say that the research conducted in Florentin started from a desire to tackle two widespread ideas: 1) the disintegration of territory due to globalization and 2) the production and multiplication of non-places. In the context of globalized city, does globalization really annihilates territory and sense of place? And is globalization a destructive matter for space or place-related identities; knowing what a strong engine globalization is for mobility, for the re-composition of references - either social or spatial - and for the diversification of our surroundings? This relation between society and space is obviously not a new topic. But it needs to be re-interrogated today as globalization keeps on blurring this wellknown - yet mysterious - equation which puts identity and place in balance. Especially if we agree that globalization constantly reshuffles local and global scales. This is why and how I investigated the neighborhood of Florentin; taking it as a place where to grasp the new layouts induced by the globalization of the city; and as a space where to observe social transformations at large. Here is the key to the title of this article: the neighborhood of Florentin is a window to the globalization of both the city and the country. In fact, this neighborhood provides a particularly rich arena for exploring the dynamics of place-making and of place transformation. Plus, and this is somehow new, researching on Florentin, allows to be dedicated to the complexity of today's urban dynamics from an everyday life point of view and to transcend what U. Beck (2005) calls the "methodological nationalism" prevalent both in the Israeli Social Sciences and in the French research on Israel/Palestine.

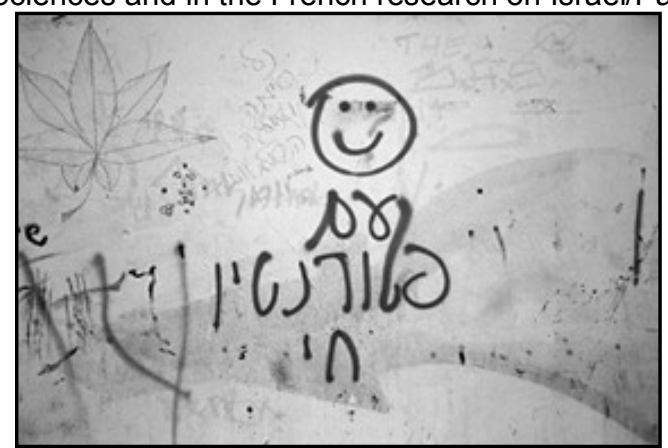

Fig. 4 - Graffiti "Am Florentin hair” - "the people of Florentin lives" Florentin 2008

It is one of my arguments that Florentin offers a great arena for capturing the processes taking place nowadays in the Israeli society through a detailed observation and analysis of gentrification, migration, urban activism and of the production of urban identities. The picture reproduced above (Fig. 4) summarizes most of what has been just said and it is one example of a graffiti you can find on many walls of Florentin. Working on globalization, no doubt it is a detail but I suggest taking it as an informative one. It reads "Am Florentin hai": "the people of Florentin lives" and is written in green and decorated with a

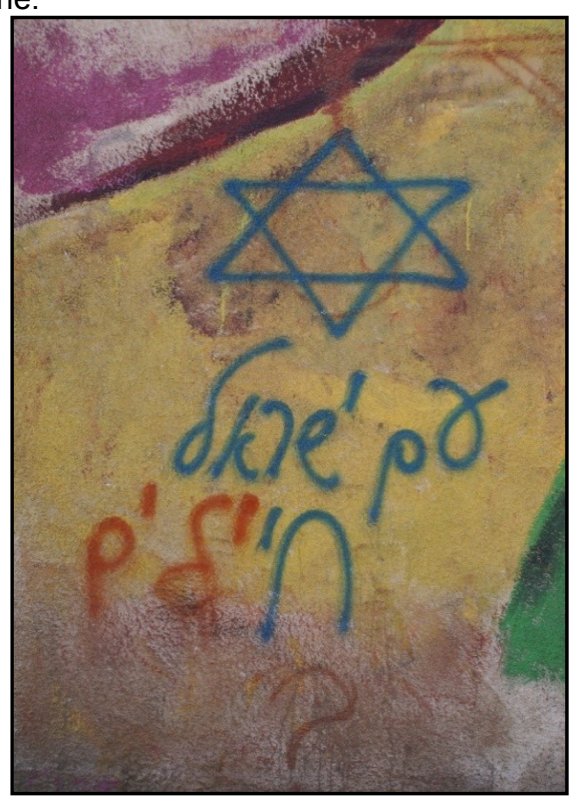

Fig. 5 - Double graffiti and play on the words: "am Israel hai" - "am israel haialim" - "the people of Israel is alive" - "Israel is a people of soldiers" - Florentin 2008. 
smile. It can be analyzed as an illustration of how Florentin is identified as a neighborhood with a specific - or defined - identity and how people identify with this neighborhood, to the point of calling themselves "the people of Florentin". This meaning is particularly strong as the "people of Florentin" actually echoes another graffiti spread, this time, all over Tel Aviv (Fig. 5).

This second graffiti states "am Israel hai": "the people of Israel live". The smile and probable humor of "the people of Florentin lives" is here replaced by a Star of David painted in blue. Both the blue color and the Star of David, in this context, immediately give the graffiti a nationalist tone ${ }^{21}$. In this game of echoes with the walls of the city as go-betweens, another statement can be read on the same figure 5 . Letters have been added at the end of the graffiti to change and maybe invert - its meaning from the "people of Israel live" to "Israel is a people of soldiers". Through these two images (Fig. 4 and Fig. 5), we already reach many layers of meaning; relating to different ways of identification to space, place and territory, including national issues and a reference to war. And although it needs to be more detailed and pursued the simple use of these two images also indicate new paths for practicing geography. They also raise the question of the elements and angles through which we analyze the relations from society and people to space and place. This remarks leads here to a central point and to the choice of the South of Tel Aviv for an exploration of main and global geographical issues. If in the IsraeliPalestinian context Tel Aviv is regarded as the global city, the neighborhoods of the south of the city have mainly remained aside from this global narrative and from the recognition of Tel Aviv as a central place and as the high-tech economy and development lung of the country. But Florentin, like other marginal places "speak" about the center and tells us much about what is going on today in Tel Aviv.

\section{Identification, history and expanded diversity in Israel}

One striking example of this, once we understand why Florentin, despite of being one of Tel Aviv historical neighborhoods, remained "out of the map", is the presence of migrant workers; living, working and buying in the streets of Florentin. Southern neighborhoods of Tel Aviv like Florentin - although the imprint of migrant workers is stronger in adjacent neighborhoods such as Shapira or Neve Sheanan and both neighborhoods are strongly identified with the presence of migrant workers - are where the migrant workers from Asia, Europe and Africa settled since 10 to 20 years $^{22}$. The "new" central bus station of Tel Aviv, East of Florentin, aggregates those "new faces" of Israel and they have constituted, I must say, what drew my attention to this part of the city. For different reasons that can't be detailed here, their presence is an opportunity to get into globalization not only through reading the high rises we now see all over Tel Aviv, but also through the globalization of the city population. The migrant workers are estimated to constitute today between 10 to $13 \%$ of the country's labor force and started to arrive mostly after the Israeli borders started to close to the Palestinian workers which since 1967 constituted a massive and cheap labor force for Israel. By settling mostly in Tel Aviv, and in Tel Aviv mostly in the southern neighborhoods of Tel Aviv, they reinitiate Florentin as a landing - starting place in the country. They inscribe themselves somehow in an immigration history, a history of mobility, many traces of can be found in Florentin, through street names, shop signs such as Thessaloniki bakeries, Persian restaurants and more recently through Indian-like places where young Israelis coming back from India like to gather and maintain the feeling of traveling and being abroad.

21) In 1983, the Israeli singer Ofra Haza competed at the Eurovision with the song "Am Israel Hai". The nationalist understatement of the song was reinforced by the fact that the contest took place in Munich, some years after the Munich Olympic Games. It was criticized for bringing politics into a recreational event.

22) See Table 2 for Central Bureau of Statistics computed data from 1996 to 2008 on the number of entries in Israel with a work visa by continent and country of origin. 
The population of Tel Aviv and the repartition of the population of Florentin by age groups from 1986 to 2009

\begin{tabular}{|c|c|c|c|c|c|c|c|}
\hline \multirow[t]{2}{*}{ YEAR } & \multirow{2}{*}{$\begin{array}{l}\text { Population } \\
\text { of Tel Aviv }\end{array}$} & \multirow{2}{*}{$\begin{array}{l}\text { Population of } \\
\text { Florentin }\end{array}$} & \multicolumn{5}{|c|}{$\begin{array}{c}\text { Florentin's population by age group } \\
\text { (\% of the total population of the neighborhood) }\end{array}$} \\
\hline & & & $0-14$ & $15-24$ & $25-44$ & $45-64$ & +65 \\
\hline 1986 & 320258 & 3105 & * & & & & \\
\hline 1987 & & 2862 & & & & & \\
\hline 1988 & 317806 & 2760 & & & & & \\
\hline 1989 & 321715 & 2565 & & & & & \\
\hline 1990 & 339354 & 2410 & 21.8 & 5.1 & 28.8 & 20.1 & 24 \\
\hline 1991 & 353242 & 2562 & 23.7 & 5.1 & 29.4 & 20.2 & 22 \\
\hline 1992 & 356911 & 3188 & 25.3 & 6.3 & 32.3 & 18.8 & 17 \\
\hline 1993 & 357367 & 3311 & 23.8 & 8.7 & 33.2 & 18.7 & 16 \\
\hline 1994 & 355197 & 3309 & 22.2 & 9.6 & 33.9 & 19.2 & 15 \\
\hline 1995 & 348245 & 3092 & 20.8 & 10.7 & 34 & 20.1 & 14 \\
\hline 1996 & 349217 & $4700^{* *}$ & 19.5 & 11.7 & 35.5 & 18.9 & 14 \\
\hline 1997 & 348570 & 3710 & 13.4 & 14.7 & 39.1 & 18 & 15 \\
\hline 1998 & 348117 & 3695 & 12.7 & 14.9 & 41.2 & 17.2 & 14 \\
\hline 1999 & 350753 & 3582 & 11.9 & 14.1 & 44.7 & 16.9 & 22 \\
\hline 2000 & 354428 & 3641 & 10.6 & 14 & 46.7 & 17.3 & 11 \\
\hline 2001 & 358800 & 3866 & 9.8 & 14.3 & 47.7 & 17.8 & 10 \\
\hline 2002 & 360400 & 3943 & 9.2 & 13.7 & 49.8 & 17.8 & 9.5 \\
\hline 2003 & 363387 & & & & & & \\
\hline 2004 & 371400 & 3913 & 8.9 & 12.5 & 51.5 & 18.1 & 9 \\
\hline 2005 & 378902 & 3972 & 8.5 & 11.1 & 54.3 & 17.5 & 8.6 \\
\hline 2006 & 384399 & 4205 & 7.7 & 10.5 & 57.2 & 17 & 7.6 \\
\hline 2007 & 390068 & 4502 & 7.4 & 9.7 & 59.1 & 9.7 & 6.9 \\
\hline 2008 & 392500 & 4878 & 6.6 & 9.7 & 61 & 17 & 5.7 \\
\hline 2009 & & 5197 & 6.6 & 9.2 & 62.8 & 16.8 & 4.6 \\
\hline
\end{tabular}

* Empty boxes correspond to missing data.

** This figure is an estimation.

Source: Municipality of Tel Aviv Jaffa, Statistical Yearbook (1986-2010), computed data.

Exploring sense of place and identity and territorial constructions in the global city of Tel-Aviv today raises the presence and of the foreign workers and the political steps the Israeli government took towards this "question". Here, one aspect that highly connects the foreign workers community, although "foreign", to the double issue of identity and territory is citizenship. Even though, the question of citizenship, as being a link between identity and territory, reminds us on a daily basis how sensitive it is in the Israeli-Palestinian context. Consequently, it is crucial to emphasize the major change the presence of foreign workers and their children born in Israel have brought in this legal area. Here again, it shows how immigration - even if important, by definition marginal - can shed light and enlarge the understanding of political and social issues of the host society itself; here Israel. Saying so, it is important to add that the changes, although major in their terms and potential, are very 
modest in "quantity" and concern only a small thousand of persons. In the summer 2005, the Knesset adopted a law - to be more precise: a one-time regulation - to grant under certain conditions residential status to some foreign workers' children.

Table 2

Number of entries in Israel with a work visa

Absolute numbers and percentages of the total by continent and country of origin (1986-2008)

\begin{tabular}{|c|c|c|c|c|c|c|c|}
\hline Year & 1996 & 1998 & 2000 & 2002 & 2004 & 2006 & 2008 \\
\hline \multicolumn{8}{|l|}{ Country of origin } \\
\hline Total (absolute numbers) & 90800 & 64200 & 52200 & 33200 & 47900 & 32700 & 30300 \\
\hline Asia (\% of the total) & 40.52 & 45.32 & 44.06 & 68.97 & 78.49 & 74.61 & 70.62 \\
\hline India & 400 & 700 & 700 & 500 & 1000 & 1100 & 2700 \\
\hline Turkey & 9000 & 2900 & 1800 & 600 & 1400 & 1100 & 900 \\
\hline Lebanon & 5200 & 5400 & 900 & & & & \\
\hline Nepal & & & & & & 2800 & 2300 \\
\hline China & 3600 & 3000 & 2900 & 1800 & 2800 & 3300 & 2300 \\
\hline Philippines & 3200 & 6700 & 7600 & 7400 & 6500 & 6400 & 5500 \\
\hline Thailand & 14900 & 9000 & 8000 & 12100 & 10400 & 9000 & 5800 \\
\hline Other Asian countries & 500 & 1400 & 1000 & 500 & 1300 & 700 & 2000 \\
\hline Africa (\% of the total) & 0.44 & 1.55 & 1.14 & 0.90 & 0.20 & 0.30 & 0.66 \\
\hline Europe (\% of the total) & 54.84 & 47.81 & 52.87 & 28.31 & 20.25 & 24.46 & 26.73 \\
\hline Bulgaria & 3300 & 2400 & 2300 & 1100 & 800 & 400 & 200 \\
\hline ex-USSR & 4400 & 3400 & 4300 & 2100 & 3000 & 4300 & 5800 \\
\hline Germany & 500 & 800 & 400 & 200 & 100 & 100 & 100 \\
\hline Great-Britain & 400 & 900 & 600 & 300 & 200 & 100 & 100 \\
\hline Romania & 37900 & 19300 & 16600 & 4500 & 4800 & 2600 & 1400 \\
\hline Other European countries & 3300 & 3900 & 2400 & 1200 & 800 & 500 & 500 \\
\hline America - Oceania ( $\%$ of the total) & 1.54 & 4.67 & 3.25 & 1.80 & 0.83 & 0.61 & 1.98 \\
\hline
\end{tabular}

Source: CBS, Statistical Abstract of Israel (1996-2008) - computed data.

Criteria were quite restrictive and only few hundreds of children fulfilled them. To be eligible, children had to be born in Israel, from parents who entered the country legally, even if they overstayed tourist visa. They also had to be 6 years old and above at the time of the regulation (July 2005). First meant for children from age 10 and above, the regulation was enlarge to children from age 6 under the pressure of different lobbies and NGOs. To obtain their permit children also had to speak Hebrew; which in fact most children in schooling age do as they usually attend public schools. Israel has signed the international treaties which require equal education for all children regardless of their parents' status and public schools accept children regardless to their parents' status. Taking all the conditions in account, 600 among 2200 children in Tel-Aviv and probably 3200 in the whole country fitted in. The brothers and sisters of those children - about 300 hundreds- also got their presence in Israel legalized. All together, 
it is about 900 children who obtained a "resident status" and will at age 21 , after compliance to the military duty, have the possibility to be granted with Israeli citizenship ${ }^{23}$. Their parents also saw their situation changed and obtained, for the ones remaining in Israel, an "A5" permit to be renewed every year and giving them all civil rights, except voting ones.

In fact, in this frame, a very precise example shows how much the question of foreign immigration is linked to the specificity of the Israeli/Palestinian context. Some children obtained the legalization of their status after their father was deported. As such, those fathers would be entitled to get a title of residence themselves. But fearing that Palestinian families that were separated after the 1967 war will take advantage on this to reunite, a condition was added. Today, those deported fathers will only be allowed to come to Israel after their children are already one year in the army. As Arab Israelis are not subjected to the compulsive army service, this is a very contextual innovation. Regardless to all those restrictions, in a country where citizenship is gained through ethnic affiliation, this downswing from jus sanguinis to jus soliis is a real change ${ }^{24)}$. This one time regulation which gives status to a new community within the society will give the country a new type of "nationals" at the time the foreign workers' children will become full citizens ${ }^{25}$. This very fact should be emphasized as proving efficiency of the migrants' participatory practices and their successful negotiated membership in Israel. The foreign workers have - as Adriana Kemp puts it - enlarged the whole Israeli public sphere through a global discourse on human rights (Kemp and al., 2000: 94, 98). Nevertheless, this success needs to be balanced by the government reactions - even or also they are various and changing - which shows a clear resistance to incorporate new members, non-Jewish immigrants, into the Israeli society. And there stands probably what geographers like William Berthomière (2005) call "the limits of an Israeli cosmopolitanism".

\section{Conclusions}

Researching in Florentin and studying this marginal and trendy neighborhood pulls us into the heart of the development of Tel Aviv as a political project one century ago. The border "contained" in Florentin crystallized in the organization of the city, regarding capital and population. As it travelled in time and maintains itself, it forces us to remember that Tel Aviv started as a neighborhood of Jaffa before becoming a municipal entity and turning Jaffa into one of its neighborhoods. Therefore, diving in the present of Florentin with in-depths interviews with residents, workers and decision makers only made sense by being combined with archives research and intensive and long term observation in the streets of the neighborhood. And as we move along the past present and future of the city and jump over scales, we produce a geography soaked in its surroundings, from which to go beyond the case-study. Thereafter, Florentin gives us to read a whole range of new identities regarding state and religion, but also regarding ways of positioning and linking ourselves to the world through the place we live in. Tel Aviv and more over the South of the city is therefore an excellent place where to decipher the local/global articulation and to understand the local impact and expression of global trends. Moreover, South Tel Aviv - being the poorest part of the city - is not where we would spontaneously look for globalization and movements of capital. Still, the analyses it allows show that we can globalization can also be read through the mundane and the details of a

23) At age 21, the grown up children will have the choice between Israeli citizenship or returning to their "country of origin".

24) It is true though that "ethnic belonging" was already not the only way to obtain citizenship in Israel as Palestinians who prove an interrupted residence in Israel between May 1948 and the enactment of the Law on citizenship in 1952 are also entitled to it (Dieckhoff 1999).

25) Israeli citizens are divided between Jewish, Arab, Druze, Circassian nationals. Until recently the each person's nationality was mentioned on the identity card. 


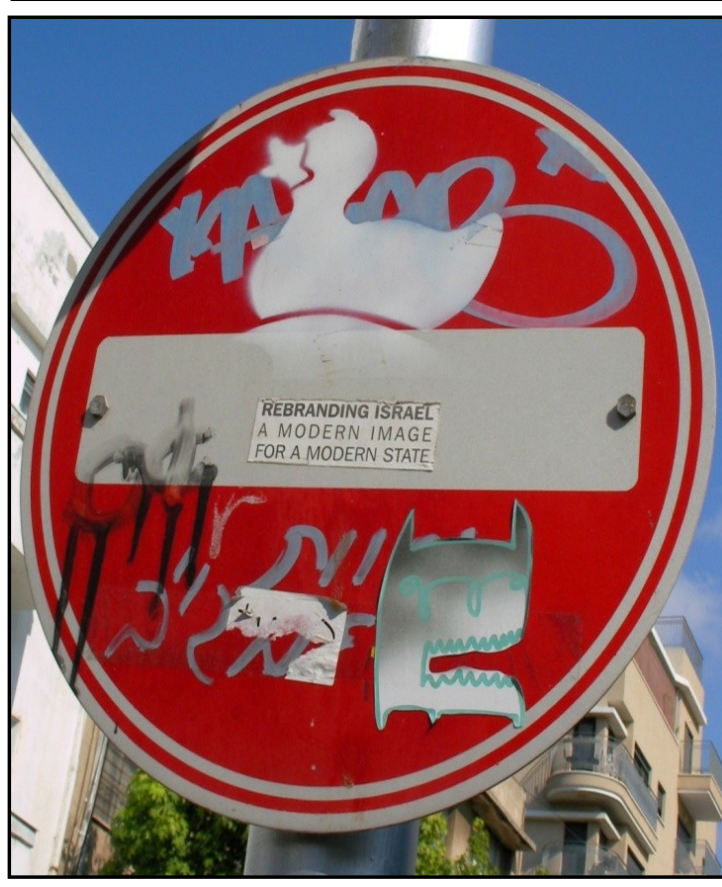

Fig. 6 - Sticker "Rebranding Israel. A modern image for a modern state", Florentin 2008. A call for putting together a new image for Israel from the streets of Florentin. marginal place.

At a more theoretical level, in-depth work on Florentin also show how much place still makes sense today; especially in places where the references and layers of time and space are diverse and accumulate rather than replace each other. In global cities, spaces open to a multiplicity of experiences and behaviors still produce strong sense of identity and identification. In Florentin, this situation is both the result of globalization as diversification and of its proper history being since its construction a place inbetween. It also shows that the globalization of our city intensify the need of identification and identification to what is seen as authentic, even in place like Florentin which are now changing and transformed by new populations settling in.

As a final conclusion, it is necessary to point out that with the impact of globalization it is the whole story of Tel Aviv that takes a different color once addressed through its southern neighborhoods. Doing so, the Bubble is grounded and sits in its political and geopolitical history and present. Therefore, the multi-analysis of the neighborhood induces the observer to take Florentin as a prism through which to observe the place, the city and the rapid transformations and inertias of the Israeli society itself. This example shows how this kind of multi-strata places is becoming a diffused "model" of place of meaning, where sense of place is reenacted through the multiplication of references and uses. Saying so, I want to point out that the choice of Tel Aviv and the multi-focal analysis of one of its "marginal" neighborhoods allow two shifts. First, it locates the reflection afar from the most mediated places of tension in a region still at war. Second, it sheds light on the mundane and the sense of place in our contemporary era of globalization from where it is less obviously traceable. This work can be sum up in three shifts: to reflect on globalization through a city that is not commonly thought of as a global city; to reflect on the evolution of a society in conflict through places that are not usually address; and last to reflect on a city and on its history through a neighborhood that was not retained as a historical neighborhood.

\section{Bibliography}

ALFASI N., FENSTER T. (2005), A Tale of Two Cities: Jerusalem and Tel Aviv in an Age of Globalization, in Cities 22 (5), p. 351-363.

ARAVOT I. (1995), Narrative-Myth and Urban Design, in Journal of Architectural Education 49 (2), p. 79-91.

BECK U. (2002), The Cosmopolitan Society and its Enemies, in Theory, Culture and Society 19 (1-2), p. 17-44. 
BECK U. (2005), The Cosmopolitan State: Redefining Power in the Global Age, in International Journal of Politics, Culture, and Society 18 (3-4), p. 143-159.

BERTHOMIĖRE W. (2005), The Emergence of a Cosmopolitan Tel Aviv : New Dynamics of Migrations in Israel, Migracijske I enicke teme, 21 (3), p. 243-253.

BIGGER G., SHAVIT Y. (2001), Mishkhounot lé-'ir (1909-1936), Historia shel Tel Aviv,

Tel Aviv, University of Tel Aviv (in Hebrew).

BONARD Y., FELLI R. (2008), Patrimoine et tourisme urbain, in Articulo - Revue de

Sciences humaines (4), p. 1-13.

CARMON N. (1999), Three Generations of Urban Renewal Policies : Analysis and

Policy Implications, Geoforum (30), p. 145-158.

DIECKHOFF A. (1999), Démocratie et ethnicité en Israël, Sociologie et sociétés 31 (2),

p. $163-173$.

EREZ T. (1996), Revitalization in the Central City. The Case of Florentin in Tel Aviv -

Jaffa, MA Thesis, Technion, Haifa.

FENSTER T., YACOBI H. (2005), Whose City is it? On Urban Planning and Local

Knowledge in Globalizing Tel Aviv-Jaffa, in Planning Theory and Practice 6 (2), p. 191-211. KEMP A., RAIJMAN R. (2004), 'Tel Aviv is not foreign to you': Urban Incorporation

Policy on Labor Migrants in Israel, in International Migration Review 38 (1), p. 26-51.

KEMP A., RAIJMAN R., RESNIK J., and all (2000), Contesting the Limits of Political

Participation: Latinos and Black African Migrant Workers in Israel, in Ethnic and Racial Studies

23 (1), p. 94-119.

KIPNIS B. (2004), Tel Aviv, Israel - A World City in Evolution: Urban Development at a

Deadend of the Global Economy, in Dela 21, p. 183-193. LEVI-FAUR D., SHEFFER G., VOGEL D. (Eds) (1999), Israel: The Dynamics of Change and Continuity, London, Frank Cass.

RAM U. (2005), Jerusalem, Tel Aviv and the Bifurcation of Israel, in International Journal

of Politics, Culture, and Society 19 (1-2), p. 21-33.

RAM U. (2008), The Globalization of Israel. McWorld in Tel Aviv, Jihad in Jerusalem,

New-York London, Routledge.

RAULIN A. (2008), Utopies locales et laboratoire social : l'exemple du $13 e$

arrondissement de Paris, L'Année sociologique 58 (1), p. 47-70.

SASSEN S. (2005), Digging in the penumbra of master categories, in The British

Journal of Sociology 56 (3), p. 401-403.

SASSEN S. (2006), Territory, Authority, Rights. From Medieval to Global Assemblages,

Princeton - Oxford, Princeton University Press.

SASSEN S. (Ed) (2007), Deciphering the Global. Its Scales, Spaces and Subjects, New

York, Routledge.

SCHNELL I. (2004), Global Spatial Lifestyle in Tel Aviv, in Geography Research Forum

24, p. 58-76.

SCHNELL I. (2007), Shenkin as a Place in the Globalizing City of Tel Aviv, in

GeoJournal 69, p. 257-269.

SCHNELL I., BENJAMINI Y. (2005), Globalization and the Structure of Urban Social

Space: The Lesson from Tel Aviv, in Urban Studies 42 (13), p. 2489-2510. SEGEV T. (2001), One Palestine, Complete. Jews and Arabs under the British

Mandate, Owl Books, New York.

SHAVIT Y. (2004), Tel Aviv, Naissance d'une ville (1909-1936), Paris, Albin Michel. ROTBARD S. (2005), Ir levana, ir shrora, Tel Aviv, Babel (en hébreu).

ROZENHOLC Caroline (in print), Foreign Workers: the Impact of Non-Jewish Immigra-

tion on Israeli Citizenship, in Bulletin du Centre de recherche français de Jérusalem, 21.

ROZENHOLC Caroline (2010), Pour une lecture re-contextualisée de Tel-Aviv, in E.

Benbassa (Ed), Israël-Palestine. Les enjeux d'un conflit, CNRS Éditions, p. 117-128. 
ROZENHOLC Caroline (2008), De la frontière à la marge. Florentin: explorations géographiques d'un quartier historique in Tsafon 55, p. 99-126.

Received at : 02.11.2010

Revised at: 06.12.2010

Accepted for publication at: 20.12 .2010 